\title{
Biological control of grass grub in Canterbury
}

TREVOR JACKSON

$M A F$ Technology, South Central, P.0. Box 24, Lincoln, Canterbury

\begin{abstract}
The grass grub (Costelytra zealandica) is a major pest of Canterbury pastures. Grass grub numbers are low in young pastures and then commonly rise to a peak 4-6 years from sowing, before declining. Grass grub numbers in older pastures fluctuate but rarely reach the same levels as the early peak. Biological control agents such as bird and invertebrate predators, parasites and diseases cause mortality in grass grub populations; the effect of predators and parasites is limited. Pathogens are common in grass grub populations. Amber disease, caused by the bacteria Serratia spp., was the disease most frequently found in population surveys in Canterbury, while milky disease (Bacillus popilliae) and protozoan diseases were less common. The level of amber disease was reduced in pastures where insecticide had been applied. Inundative applications of entomophagous nematodes and the bacterium Serratia entomophila have been tested against grass grub. A bacterial product based on $S$. entomophila is now being marketed for grass grub control.
\end{abstract}

Keywords grass grub, biological control, pathogens

\section{Introduction}

The grass grub (Costelytra zealandica) has been a pasture pest in Canterbury since the earliest days of European settlement. Despite a considerable research effort aimed at its control, grass grub remains one of the most important insect pests in the region today.

The insect is present in pastures throughout the province and numbers vary considerably depending on annual weather conditions (R.A. French unpublished). Most pasture damage occurs in the autumn and winter and is accentuated by dry autumn periods which limit the growth of pasture but allow continued development of the grass grub larvae. Periods of severe drought or cool weather, as experienced in the Canterbury high country, will delay larval development and force grass grub into a 2-year life cycle. This often results in spring damage, particularly to emerging crops. Within the limits set by climatic conditions, grass grub populations typically form a mosaic in any area, rising and falling according to pasture management practices and biological control agents operating within each paddock.

Grass grub numbers are usually low in new pasture or crops owing to high mortality during cultivation. In favourable conditions in pasture, grass grub populations will increase in a predictable fashion (East \& Kain 1982) and reach a peak 4-6 years from sowing (e.g. Kelsey quoted in Jensen 1967; Jackson et al. 1989). High levels of damage are typical in 3- to 6-year-old pastures and farmers will often respond to damage with cultivation, thereby shortening the potential life of the pasture.

After attaining a high population density, grass grub populations often collapse. This may be due to combat mortality, where larvae will bite and injure each other causing death through bacterial invasion, and starvation after destruction of the pasture (Kain 1975). Populations also collapse where there is little visible damage and adequate food supplies remain. These collapses are caused by other biological factors in- the-pasture-environment;-In-older-p.addo\& ( > 10 years) grass grub numbers are lower than in younger pastures and grass grub damage is much less likely (Jackson et a/. 1989).

\section{Biological control agents}

Once the upper limit on population size has been set by egg laying, numbers will decline within the season because of a variety of mortality factors, including both vertebrate and invertebrate predation. Birds can be important predators of grass grub. Starlings have been shown to reduce grass grub populations by $40 \%$, but are effective on only limited areas favourable to the birds (East \& Pottinger 1975). Rooks consume about $20 \%$ of the grass grub in some pastures, but in doing so cause extensive pasture damage (McLennan \& MacMillian 1983). Invertebrate predators (carabid and elaterid beetles and asilid flies) can often be found but are not usually abundant in the pasture environment (Cameron \& Wigley 1989).

Parasites of grass grub are not common (Cameron \& Wigley 1989). The only exception, a tachinid 
Table 1 Grass grub diseases and the incidence of field infections found in Canterbury.

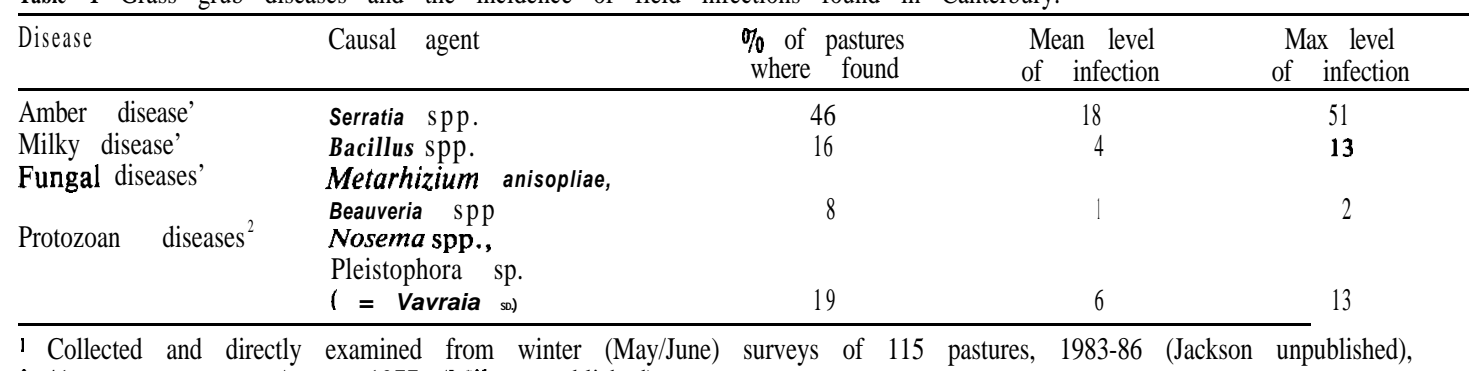

241 pasture survey, August 1977 (Miln unpublished).

parasite (Procissio cana), is found in grass grub populations in the Canterbury high country where it parasitises up to $20 \%$ of third instar larvae (Merton 1982). It is rarely found on the plains, as the adult is summer active and can parasitise only third-instar larvae in a 2-year life cycle. These occur most frequently in higher altitude grasslands.

Several surveys of grass grub diseases in Canterbury have revealed the presence of a large number of pathogens. The major diseases found in these surveys are listed in Table 1. Amber disease, caused by the bacteria Serratia spp. (Grimont et al. 1988), was the most common of the diseases readily diagnosed from field examination of larvae. This disease was first isolated in Mid Canterbury in 1981 (Trought $e t$ al. 1982). It occurred naturally in nearly half of the paddocks surveyed and in those paddocks the mean level of disease was $18 \%$ (Table 1). Grass grub populations have been monitored both before and after epizootics of amber disease. The growth of population and disease in new pastures is shown in Figure 1. Larval numbers built up to a peak 4 years from sowing then declined. Diseased larvae were uncommon in the first three years but numerous in later generations. After a disease epizootic (Figure 2), the grass grub populations declined and remained at low levels for several seasons. High proportions of amber-diseased larvae were found in the first two years after the peak. In the following years, with very low grass grub populations, no diseased larvae were found but the bacterium could still be isolated from the soil.

Milky disease caused by the bacterium Bacillus popilliae, was found at $16 \%$ of the sites but the levels of infection never reached more than $13 \%$. Higher levels of milky disease (up to 35\%) have subsequently been found on irrigated land in the Amuri basin, possibly a response to higher temperatures, as bacterial infection is temperature-dependent and requires temperatures greater than $18{ }^{\circ} \mathrm{C}$ (Fowler 1974). In the North Island, milky disease is an important mortality factor of early larval instars of the grass grub (East \& Wigley 1985).

Few cadavers infected with fungal pathogens were recorded directly in the field in the survey data in Table 1, although when larvae were reared in the laboratory at $20^{\circ} \mathrm{C}$ both Beauveria spp. and

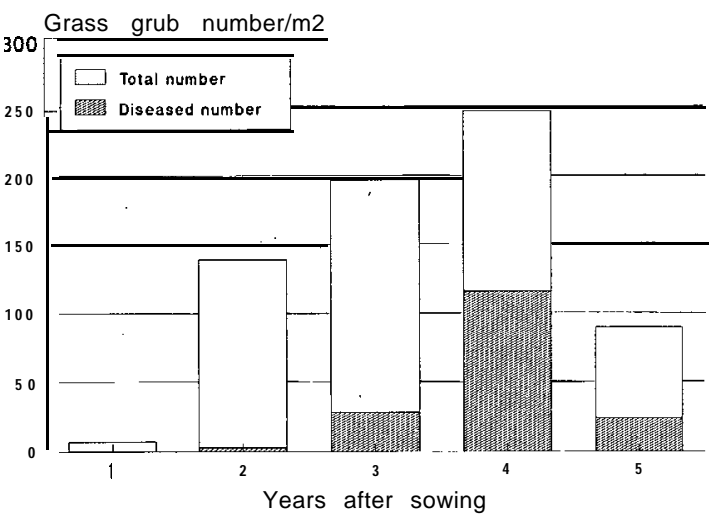

Figure 1 Grass grub population growth and development of disease in young pastures at Hinds, Canterbury. (From O'Callaghan et al. 1989).

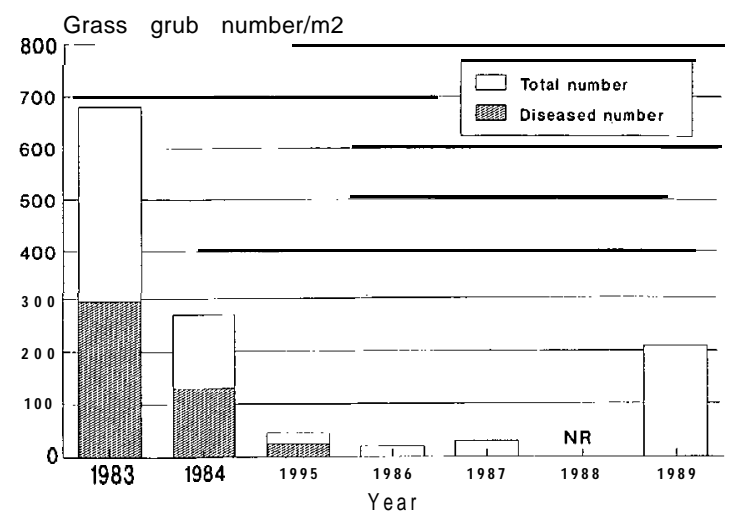

Figure 2 Grass grub population and amber disease following a disease epizootic at Fairton, Canterbury.

Metarhizuim anisopliae were common causes of mortality. Fungal infections in the field are more common with rising temperatures in the spring. Protozoan diseases of grass grub appear to be less common in Canterbury than in some other parts of the country but can occur at moderate levels (Miln 1978; Table 1). Mermithid nematodes (Psammomermis canterburis) have also been found in grass grub larvae in pasture close to the foothills (Hoy 1952; Poinar \& Jackson (in press)), and 
recently electron microscopic studies of grass grub have revealed a number of viruses that were previously unrecorded (Hess-Poinar et a/. (in press), T.R. Glare pers. comm.).

While each of the organisms listed above can affect the population within the season, effects on population regulation between seasons are harder to assess. Barlow et al. (1985) have shown that diseases, including amber disease in Canterbury, can be important regulatory factors for grass grub populations. A disease level of $>30 \%$ usually depresses a grass grub population in the next season (Jackson 1984).

\section{Manipulation of biological control agents}

While biological control will operate to some exten in all pastures, it is often not sufficient to prevent pasture damage. Therefore, ways must be sought to increase the effectiveness of biological control in pasture: by conserving or augmenting the existing biological control agents or by adding new ones.

Because predators and diseases of grass grub are more common in established, older pastures than in young pastures, older pastures appear more resistant to grass grub attack. Grass grub damage on the farm will be minimised by maintaining pastures for as long as possible between cultivations (Jackson et al. 1989). Damage in peak larval years can be limited by mob stocking or rolling and damaged pasture renovated by oversowing (French $\boldsymbol{e t}$ al. 1983). Application of insecticides, a common practice in the past, appears to reduce levels of disease among the larvae (Table 2; Miln \& Carpenter 1979; Miln 1983). This may be due to initial "population suppression reducing the number of potential hosts for the pathogen, preferential mortality of the diseased insects or to the direct effects of the chemical on the pathogen. Whatever the cause, population resurgence after insecticide application is frequently reported for grass grub (e.g. Lauren et al. 1990; East et al. 1986). Maintenance of stable pastures, without disruption by cultivation or insecticide use, seems, therefore, to be a good way to conserve natural biological control factors.

Table 2 Grass grub populations and levels of amber disease in insecticide-treated' and untreated pastures, inland Canterbury, sampled May/June 1982.

\begin{tabular}{|c|c|c|c|c|}
\hline & No. & paddocks & $\begin{array}{l}\text { Larval } \\
\text { popln } / \mathrm{m}^{2}\end{array}$ & $\begin{array}{c}\text { \% Amber } \\
\text { disease }\end{array}$ \\
\hline Treated & & 14 & 180 & 1 \\
\hline Untreated & & 16 & 230 & 11 \\
\hline
\end{tabular}

Diazinon or fensulfothion applied within 2 years of sampling, lindane applied within 5 years of sampling.
In the past decade, emphasis has been placed on the development of biological control agents which can replace chemicals for control of grass grub. Some success has been obtained with steinernematid and heterorabditid nematodes. These can be artificially cultured and applied to the pasture where levels of control have been good (Kain et al. 1982; Jackson \& Trought 1982). The nematodes can persist in the pasture for more than one season and kill larvae when the conditions are favourable (Jackson \& Wouts 1987). However, nematodes are unlikely to be immediately useful in grass grub control because the rates required for control are high and production costs are substantial. The decision whether to apply nematodes is also difficult, as best results have been obtained from late summer-early autumn applications before grass grub damage is obvious.

The development of the bacterium Serratia entomophila has been more successful. Trials carried out shortly after isolation showed that the disease could be transmitted by artificial application of bacteria (Jackson \& Trought 1982). Since those early trials, an extensive programme has been carried out to develop the bacterium as a commercial biological control agent for grass grub (Jackson 1989). This has included strain selection, development of production and application methods and safety testing. Application of the bacteria causes outbreaks of amber disease, so reducing the feeding of the larvae and protecting the pasture. Winter pasture production increases of 30 and $37 \%$ have been recorded after application (Jackson et al. 1986; Jackson 1988). A bacterial product, Invade@, is now registered as a microbial pesticide and is being marketed under a joint venture programme with -Monsanto NZ Ltd. This--year- several- hundred hectares in Canterbury have been treated with bacteria.

\section{Conclusions}

After more than a century of pasture improvement in Canterbury, grass grub is still a major pest but is under considerable pressure from natural biological controls. To achieve sustainable, long-term grassland systems we have to make use of those factors which already exist and are working against grass grub. Amber disease is one such factor, and promises to become an important component of pasture management systems for grass grub control. It should not, however, be viewed as a single solution to grass grub, but combined with other, complementary management practices such as grazing management and new pasture species, to reduce grass grub damage. Integrated pest management in the future must make full use of natural controlling factors and thus develop low cost systems which are sustainable in output of high quality products. 


\section{REFERENCES}

Barlow, N.D.; Miln, A.J.; Thomson, N.A.; Kain, W.M. 1985. A simple population model for pest/disease interactions in pastures. Proceedings of the 4th Australasian conference on grassland invertebrate ecology: 182-190.

Cameron, P.J.; Wigley, P.J. 1989. Costelytra zealandica (White), grass grub (Coleoptera: Scarabaeidae). Pp 9-16. In Cameron, P.J.; Hill, R.L.; Bain, J.; Thomas, W.P. (eds). A Review of Biological Control of Invertebrate Pests and Weeds in New Zealand 1874 to 1987. CAB International.

East, R.; Kain, W.M. 1982. Prediction of grass grub, Costelytra zealandica (Coleopteta: Scarabaeidae) populations. NZ entomologist 7: 222-227.

East,. R.; Pottinner, R.P. 1975. Starling (Sturnus virlearis L.) predation on grass grub (Costelytra zealandica (White), Melolonthinae) populations in Canterbury. NZ journal of agricultural research 18: 417-452.

East, R.; Prestidge, R.A.; Robertson, L.N. 1986. Recent advances in pasture pest management in the northern North Island. NZ journal of ecology 9: 101-109.

East, R; Wigley, P.J. 1985. Causes of grass grub (Costelytra zealandica (White) population collapse in the northern North Island of New Zealand. Proceedings of the 4th Australasian conference on grass/and in vertebrate ecology: 19 I-200.

Fowler, M. 1974. Milky disease (Bacillus spp) occurrence and experimental infection of larvae of Costelytra zealandica and other Scatabaeidae. NZ journal of zoology 1: 97-109.

French, R.A., Pearson, J.F., Vartha, E.W. and Fraser T. J. 1983. Grass grub: Coping without chemical control. Proceedings of the NZ Grassland Association 44: 217-221.

Grimont, P.A.D.; Jackson, T.A.; Ageron, E.; Noonan M.J. 1988. Serratia entomophila sp. ov. associated with amber disease in the New Zealand grass grub, Costelytra zealandica. International journal of systematic bacteriology 38: 1-6.

Hess-Poinar, R.; Jackson, T.A.; Poinar, G.O. 1991. Electron microscope evidence of a new virus in the grass grub Costelytra zealandica (White) (Coleoptera:Scarabaeidae). Journal of invertebrate pathology: In press.

Hoy, J.M. 1952. Note on the occurrence of nematodes in larvae of Odontria zealandica White. NZ entomologist I: 5-6.

Jackson, T.A. 1984. Honey disease, an indicator of population decline in grass grub. Proceedings of the 37th New Zealand weed and pest control conference: 113-116.

Jackson, T.A. 1988. Effect of infection by the bacterium Serratia entomophila on feeding and pasture damage by grass grub larvae. Proceedings of the 4lst NZ weed and pest control conference: 135-137.

Jackson, T.A. 1989. Development of Serratia entomophila as an inundative biological control agent for the grass grub, Costelytra zealandica. Proceedings of the 5th Australasia conference on grassland invertebrate ecology: 146-152.

Jackson, T.A.; Barlow, N.D.; Pearson, J.F. French, R.A. 1989. Effect of paddock rotation practices on grass grub (Costelytra zealandica) damage in Canterbury. Proceedings of the 5th Australasian conference on grassland invertebrate ecology: 146-152.
Jackson, T.A.; Pearson, J.F.; Stucki, G. 1986. Control of the grass grub, Costelytra zealandica (White) (Coleoptera: Scatabaeidae), but application of the bacteria Serratia spp. causing honey disease. Bulletin of entomological research 76: 69-76.

Jackson, T.A.; Trought, T.E.T. 1982. Progress with the use of nematodes and bacteria for the control of grass grubs. Proceedings of the 35th $\mathrm{NZ}$ weed and pest control conference: $103-106$.

Jackson, T.A. Wouts, W. 1987. Delayed action of an entomophagous nematode (Heterorhabditis sp (V16)) for grass grub control. Proceedings of the 40th NZ weed and pest control conference: $33-35$.

Jensen, R.C. 1967. Economics of pasture pest control. Proceedings of the 20th NZ weed and pest control conference: 135-149.

Kain, W.M. 1975. Population dynamics and pest assessment studies of grass grub (Costelytra zealandica (White) Melolonthinae) in the North Island of New Zealand. PhD thesis, Lincoln College, University of Canterbury.

Kain, W.M.; Bedding, R.A.; van der Mespel, C. J., 1982. Preliminary investigations of parasitic nematodes for grass grub (Costelytra zealandica White) control in central Hawke's Bay of New Zealand. NZ journal of experimental agriculture 10: 447-450.

Lauren, D.R.; Henzell, R.F.; Wrenn, N.R. 1990. Grass grub (Costelytra zealandica) population trends following insecticide applications. NZ journal of agricultural research 33: 159-163.

McLennan, J.A.; McMillan, B.W.H. 1983. Predation by the rook. Corvus frugilegus $\mathrm{L}$. on larvae of the grass grub Costelytra zealandica (White) in Hawke's Bay, New Zealand. NZ journal of agricultural research 26 : 139-145.

Merton, J.M. 1982. Interations of the tachinid, Procissio cana with its host the New Zealand grass grub, Costelytra zealandica. Proceedings of the third Australasian conference on grassland invertebrate ecology: 161-168.

Miln, A.J. 1978. Protozoan parasites of Costelytra zealandica Coleoptera: Scarabaeidae) in New Zealand. NZ entomologist 6: 392-399.

Miln, A.J. 1983. The effects of different times of insecticide application on disease incidence in grass grub populations. Proceedings of the 36th $\mathrm{NZ}$ weed and pest control conference: 199-202.

Miln, A.J.; Carpenter, A. 1979. Relationship between pathogens and insecticides in grass grub. Proceeding of the 32nd NZ weed and pest control conference: 92-95.

O'Callaghan, M.; Jackson, T.A.; Noonan, M.J. 1989. Ecology of Serratia entomophila in soil. Proceedings of the 5th Australsian conference on grassland invertebrate ecology: 69-75.

Poinar, Jr., G.O.; Jackson, T.A. 1991. Psammomermis canterburis n.sp. (Mermithidae: Nematoda) parasitic in the New Zealand grass grub, Costelytra zealandica (Scarabaeidae: Coleoptera). Revue de Nematologia: In press

Trought, T.E.T.; Jackson, T.A.; French, R.A. 1982. Incidence and transmission of a disease of grass grub (Costelytra zealandica) in Canterbury. NZ journal of experimental agriculture 10: 79-82. 